RESENSI BUKU

\title{
Hubungan Ekonomi Kawasan Pasifik Abad Duapuluh Kerjasama atau Konflik
}

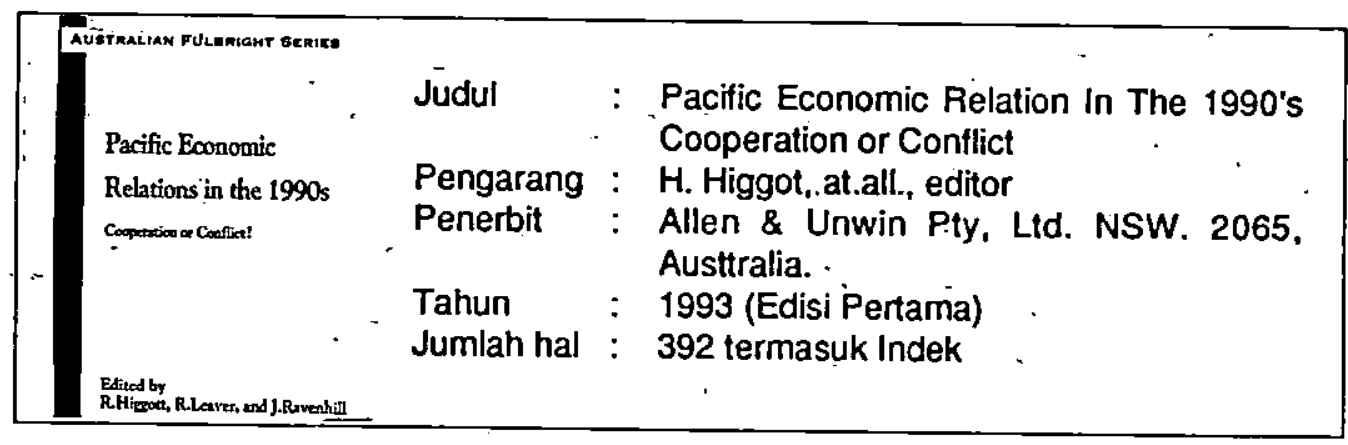

\section{I}

Buku ini berisi kumpulan karya tulis asli dải beberapa palar politik Ekonomi Internasional yang mencakup 15 topik bahasan. Tujuanutama penerbitan buku ini adalah untuk mengangkat studi Politik Ekonomi sejajar dan mencoba menjawabpersoalan kerjasama ekonomi internasional di kawasan Pasifik di masa depan. Tema tersebut telah dibahas dalam sebuah simposium yang diselenggarakan oleh Lembaga Fulbright Australia- Amerika di Canberra bulan Desember 1991.

Terdapat perbedaan sudut pandang mengenai kerangka konsep yang digunakan para ahli dalam memahami istilah "manajemen hubungan ekonomi intemasional" dikawasan Pasifik. Sebagian para ahli memahàmi manajemen dalam arti pengaturan (administering) dan sebagaian lain memahaminya sebagai menempatkan problema kawasan Pasifik bagian dari sistem yang lebih luas atau global (subsisting). Penyelenggara simposium sendiri cenderung untuk menyerahkan masalah tersebut kepada para pembaca mana yang di angggap lebih penting dan perlu.

Dari pengantar yang diuraikan oleh para penyunting dapat disimpulkan bahwa kawasan Pasifik yang menjadi fokus sorotan dalam buku ini merupakan kawasan yang sedang mengalami pergolakan atau dinamika yang besar, gerakan orientasi ekonomi luar negeri yang ajaib, luar biasa, di kawasan sepanjang negeri negeri Ásia Timur. Pergolakan ini menimbulkan ancaman yang tajam bagi kemunduruan kegiatan ekonomi di kawasan lainnya dan pusat kegiatan ekonomi global bergeser menuju kawasan Pasifik. Ketergantungan negara-negara Pasifik menuntut pemikiran perlunya mengembangkan suatu kebijaksanaan yang menguntungkan bagi semua pihak di kawasan tersebut.

II ·

Secara ringkas, masalah-masalah yang dibahas oleh parapenulis meliputilima 
persoalan pokok, pertama, hubungan perdagangan antara Amerika Serikat dengan Negara negara di Kawasan Pasifik, khususnya Jepang yang tidak berimbang (imbalance), kedua, pilihan-pilihan altematif dalam menciptakan suatu bentuk kerjasama yang saling menguntungkan semua pihak dan mencegah timbulnya konflik, ketiga, efektivitas lembaga kesepakatan internasional dalam menghindari konflik sepertiGATT, OECD, dsb, keempat : bagaimana menigkatkan kerjasama ekonomi regional sepertiNAFTA, APEC, MBCs, dan bangkitnya negara-negara industri baru di Asia (NICs) serta program aksi (Action-Program) yang dapat dilakukan bersama untuk lebih meningkatkan kerjasama ekonomi internasional.

Para penulis sepakat bahwa dua dekade terakhir tiada perkembangan ekonomi global secepat Kawasan Pasifik yang melahirkan konflik ekonomi, khususnya anatara Amerika dan Jepang (Richard Higgott,at.all), menciptakan situasi penuh gangguan, ancaman dan kejahatan yang gawat ( $\mathrm{J}$. Gerald Ruggie). Perkembangan ekonomi internasional Jepang telah semakin kuat, surplus ekspor teknologi yang semakin maju, pemasok dana yang semakin meningkat, penbeeri bantuan yang terbesar menjadikan Jepang sebagai pemimpin ekonomi global sementara negara-negara lain 'dalam keadaan sakit parah. Jepang dengan dukungan negara-negara industri baru (NICs) mengalami pertumbuhan di atas 10\% pertahun. Jepang, NICs dan A A sean menguasai 43\% pada tahun 1969 menjadi $53 \%$ pada tahun 1990 dari seluruh perdagangán dunia. Kérjasama negara- negara Pasifik (APEC) menguasai 60\% dari seluruh eksport dari kawasan Asia Pasifik. Perdagangan AS-Jepang dalam 20 tahun terakhirmengalami defisit sementara Jepang surplus (J. David Richardson). Chalmer Johnson lebih tajam dalam menilai Jepang sebagai pihak yang membunyikan alam putusnya. komunikasi AS-Jepang (communication disconnection), mencuatnya nasionalisme Jepang dan bangkitnya militerasme Jepang dalam melindungi kepentingan dagangnya.

Krisis ketidakseimbangan (imbalance) hubungan AS-Jepang telah merambah dari sektor produksi ke sektor keungan dan telah mendorong Amerika untuk melakukan tindakan proteksi serta penủunan kurs - dollar terhadap uang Yen yang mengakibatkan Jepang kelabakan. Ruggie berpendapat bahwa politik proteksi adalah solusi yang tidak relevan, bodoh, salah untuk perkembangan jangka panjang. Higgott lebih melihat hikmah dari situasi tidak seimbang itu untuk membuka kerjasama ekonomi dalam memecahkan masalah-masalah besar dilandasi suatu ide yang baru, kelembagaan yang kuat, kepeminpinan baru.

Menurut Chalmer Johson, hubungan asymetric antara AS Jepang tidak terlepas dari kelemahan kedua belah pihak. Jepang telah kelewat besar dalam mengambil alih kemampuan dalam memperbaiki dosa pembangunan industri exonominya dan berakibat mandegnya peran kepemimpinan AS serta kekuarangpekaan Amerika dalam mengantisipasi pasca mtuhnya komunisme di Asia Barat. Ruggie bèrpendapat, apa yang perlu dilakukan adalah " allocated market share", harmonisasi OECD dalam mengadakan penyesuaian kebijaksanaan 
produksi dan hasil yang seimbang bagi semua pihak. Dengan menukil konsensus Kynesian Buggiele lebih sependapat perlunya pembaharuan ekonomi Pasifik sehingga mampu menciptakan suatu model ekonomi global sebagai suatu keseluruhan, melintasi batas-batas territorial ekonomi nasional, desentralized.

Richardson dan Richard Leaver mengakhiri pembicaraan mengenai altematif pilihan dengan mengemukakan pandangan baru yang lebih pragmatis. Kompetisi dan pasar terbuka merupakan keadaan yang berimbang dalam mengembangkan tata ekonomi intemasional yang baru, membuka suatu manajemen baru sebagai suatu harapan yang realistik berdasar pengalaman empirik hubungan Amerika Jepang selama ini.

Tentang efektivitas lembaga kerjasama internasional Ruggie berpendapat bahwa GATT tidak menyelesaikan masalah bahkan semakin mempertajam hubungan asimetris yang telah ada. Negosiasi-negosiasi-dengan negara-negara terlibat berjalan lambat tidak sesuai jadwal. Kerjasama G7 (AS Inggris, Canada, Perancis, Jerman, Itali danJepang) yang dianggap berhasil di dalam mengendalikan ekonomi moneter ternyata masih menghadapi hambatan yaitu terdapatnya kepentingan masing-masing negara yang tidak selalu sama, sikap serta kemauan masing-masing negara yang masih berbeda untuk menerima ketentuanketentuan bersama dan kebijakan negara dalam bidang politik sertackonominya masing-masing „सeadaan seperti itu rerjadi pada kerjasama NAFT $\dot{A}$, OPTAD maupun OECD.

Akhimya dapat dikemukakan pokok- pokok pikiran yang dapat dirumuskan tentang bagaimana usaha yang mungkin ditempuh 'dalam mengantisipasi perkembangan ekonomi Kawasan Pasifik serta segala permasalahan yang timbul dalam beberapa program aksi :

Pertama : permasalah pokok adalah bagaimana mengatasi problem ketidak seimbangan atau economic - imbalance sebagai akibat ekspansi ekonomi Kawasan Pasifik baik dari sisi domestik maupun intemasional secara simultan. Altematif yang mungkin dilakukan adalah " adjustment proses" yang mengarah pada tumbuhnya kerjasama ekonomi di masa depan.

Kedua': hubungan kerjasama yang paling tepat adalah hubungan multilateral yang harus terus diusahakan sebagai suatu keseluruhan (as a whole system ) tidak menganak emaskan Amerika tetapi yang. lebih menjanin adanya pertumbuhan, efisiensi dan stabilitas ekonomi, tidak ada ekonomi surplus atau sebaliknya defisit tetapi suatu kerjasama ekonomi yang seimbang (equilibrium) terbebas dari ikatan bilateralism, patronage maupun assimilasi satu dengan yang lain, tidak mengenal hegemoni atau regime ekonomi negara tertentu, niengutamakan konsultasi, pertukaran informasi, keterbukaan serta sharing problem solving.

Ketiga : dalam mengembangkan kerjasama ekonomi Pasifik diperlukan koordinasi di antara negara-negara Asia Pasifik sendiri dengan memperhatikan halhal sebagai berikut :

a. Interdependensi dan globalisasi menentukan hubungan ekonomi intemasional sekarang oleh karena itu manajemen yang harus dikembangkan 
adalah manajemen ekonomi global dengan memperhatikan masyarakat ekonomi yang sudah ada seperti NAFTA, MNCs, dll.

b. Pendekatan teoritis atau realistis seringkali menimbulkan masalah. Yang

- penting dan perlu dikembangkan adalah suatu pendekatan yang dapat menumbuhkan keseimbangan antara peran negara, kckuasaan dan kepentingan ekonomi internasional dan kemajuan (progress).

c. Kerjasama ekonomi sclama ini banyak dilakukan diluar constitutive process. Untuk penerimaan dan kebutuhan kerjasama masa depan diperlukan pengaturan dan perlindungan hukum (reordering) yang dapat ditcrima olch semua pihak.

Keempat : dalam membangun kembali hubungan AS-Jepang perlu memperhatikan dan berpijak pada kepentingan-kepentingan nyata serta potensi atau kekuatan yang dimilki masingmasing. Mengembangkan kerjasama ekonomi yạ́ng saling menguntungkan dengan memperhatikan perbedaan idelogi serta politik. Kerangka kerjasama memerlukan landasan aturan hukum seperti dicontohkan "Uruguay Round" yang dirasakan lebih bersahabat terutama yang berkaitan denngan Jepang.

III

Membaca buku ini terasa seolah dibawa berkeliling dunia menyaksikan peta pergolakan ckonomi berbgai nagsa. Ditulis oleh tidak kurang 14 orang pakar ekonomi intemasional, disajikan dalam bạhasa yang berbeda dengan kcbiasaan penulis-penulis barat umumnya, ilmiah. singkat tetapi padat dengan informasi. Akan menjadi lengkap pemahaman kita jika dibaca pula buku lain yang tidak dapat dipisahkan yaitu " A Two Minute Waming for American Business" karangan Grayson O'Dell, 1988, "The Newly Industrializing Countries of Asia" karangan Gerald Tan, 1992. Buku ini dilengkapi dengan daltar indek menurut nama dan subjek serta daftar bibliografi yang jumlahnyalcbih dari 700 buah, dicetak diatas kertas HVS 80 gram serta sampul yang luxs. Bagi para dosen dan mahasiswa yang mendalani ekonomi intemaśional buku semacam ini mútlak harus dibaca jika tidak ingin tertinggal informasi (Zainal Abidin) 